\title{
PENGAKUAN, PENGUKURAN, PENYAJIAN, DAN PENGUNGKAPAN ASET KELOLAAN PADA \\ LEMBAGA AMIL ZAKAT')
}

\author{
Ghufraanaka \\ Program Studi S1 Ekonomi Islam-Fakultas Ekonomi dan Bisnis-Universitas Airlangga \\ Email : fronnaonna@ymail.com \\ Dina Fitrisia Septiarini \\ Departemen Ekonomi Syariah-Fakultas Ekonomi dan Bisnis-Unversitas Airlangga \\ Email : dina.fitrisia@gmail.com
}

\begin{abstract}
:
The purpose of this research is to assess the implementation of accounting aspects such as recognition, measurement, presentation and revelation of zakat transactions within LAZISMU in regards to PSAK 109 concerning zakat accounting. This research employs a qualitative descriptive approach with case study methodology. The technique of analysis used within this research is the domain analysis technique. The research determines two domains in relation to zakat accounting, which are acquisition, management and distribution of zakat, infaq and shadaqah. Results suggest that in the aspect of recognition and measurement, LAZISMU demonstrated compliance to the PSAK 109 during the acquisition of zakat, infaq and shadaqah, however LAZISMU failed to show compliance in regard to the aspects of revelation and presentation during the acquisition process. In conclusion, LAZISMU are not compliant to the general guide of zakat accounting, mostly due to lack of able personnel in LAZISMU.
\end{abstract}

Keywords : Syariah Accounting, PSAK 109, Asset Management, Zakat Accounting

\section{PENDAHULUAN}

\section{Latar Belakang}

Di Indonesia mayoritas penduduknya beragama Islam, salah satu instrumen pemeratan pendapatan adalah Zakat, Infak, dan Shadaqah (ZIS). Kedudukan lembaga zakat dalam lingkungan yang semakin maju dan kompleks sangat penting, seiring dengan semakin majunya umat, baik dari segi ekonomi, ilmu pengetahuan maupun keyakinan beragama, maka diharapkan jumlah muzakki (pembayar zakat) akan bertambah dan juga kuantitas zakat akan meningkat. Dalam hal ini Lembaga Amil Zakat (LAZ) dan Badan Amil Zakat (BAZ) merupakan lembaga kepercayaan publik dalam hal penghimpun dana dan penyaluran dana zakat (Ferdiansyah: 2013). Masyarakat wajib menjalankan zakat, infak, dan shadaqah sesuai dengan ajaran Islam untuk berada di jalan Allah SWT.

Lembaga Amil Zakat merupakan institusi resmi yang ditujukan untuk menciptakan pemerataan dan keadilan bagi masyarakat, sehingga taraf kehidupan masyarakat dapat ditingkatkan. Zakat sebagai rukun Islam ketiga merupakan instrumen ajaran Islam yang berfungsi sebagai pemerataan pendapatan, bagi yang mampu wajib menyedekahkan sebagian hartanya untuk orang yang lebih membutuhkan agar terjadi kemaslahatan di masyarakat. 
Ghufraanaka, et al/Jurnal Ekonomi Syariah Teori dan Terapan Vol. 3 No. 5 Mei 2016: 375-390; PENGAKUAN, PENGUKURAN, PENYAJIAN, DAN PENGUNGKAPAN ASET KELOLAAN PADA LEMBAGA AMIL ZAKAT

Pencatatan transaksi zakat diatur dalam PSAK 109. Besarnya potensi zakat di Indonesia maka pengelolaan zakat yang harus dilaksanakan secara profesional oleh Organisasi Pengelola Zakat (OPZ). Dalam Bab III Undang-Undang No. 38 tahun 1999, Organisasi Pengelola Zakat (OPZ) terdiri dari dua jenis, yaitu Badan Amil Zakat (pasal 6) yang dibentuk oleh pemerintah dan Lembaga Amil Zakat (pasal 7) yang dibentuk oleh masyarakat (Sudarsono, 2008:262).

Menurut Zuhayly (2008: 280) zakat disalurkan kepada delapan golongan asnaf: (1) Fakir, (2) Miskin, (3) Kelompok amil (petugas zakat), (4) Kelompok muallaf (orang yang baru masuk Islam), (5) Memerdekakan budak, (6) Kelompok gharimin atau kelompok yang berutang, (7) Fi sabilillah, (8) Ibnu sabil.

Zakat dapat disalurkan kepada amil, dalam pengelolaan zakat tersebut harus berlandaskan Al-Qur'an dan Al-Hadits. Sebagai umat muslim memiliki kewajiban membayar zakat dari sebagaian harta yang dimilikinya. Dalam Islam telah ditentukan membayar zakat sebesar 2,5\% dari pendapatannya. Muzzaki menyalurkan zakatnya kepada sebuah lembaga amil zakat dan sebagai amanah lembaga amil zakat harus menyalurkan zakat tersebut dengan baik dan benar, sebagian dana zakat digunakan untuk aset kelolaan. Lembaga Amil Zakat dalam mengelola aktivitas asetnya tidak lepas dari pencatatan akuntansi. Pencatatan pelaporan keuangan harus dilakukan secara transparan, akuntable, baik dan benar agar kebenaran pencatatan pelaporan keuangan dapat dipercaya. Organisasi Pengelola Zakat (OPZ) mempunyai tugas mengelola zakat memerlukan laporan keuangan untuk mempermudah kinerjanya. Perintah untuk melakukan pencatatan transaksi jual beli ataupun transaksi muamalah terdapat dalam Al-Qur'an surat Al Baqarah 282:

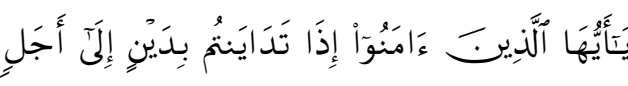

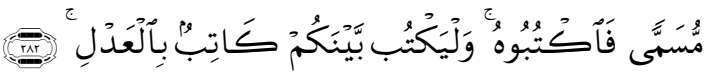
ya>'ayyuha>'l-lazil>na 'amanu> 'izla> tada $>$ yantum bidaynin 'ila> 'ajalim musamman fauktubu>hu walyaktub baynakum ka>tibu bi 'l'adli.

Artinya: "Hai orang-orang yang beriman, apabila kamu bermu'amalah tidak secara tunai untuk waktu yang ditentukan, hendaklah kamu menuliskannya. dan hendaklah seorang penulis di antara kamu menuliskannya dengan benar........." (Departemen Agama Rl, 2007).

Menurut Baznas Kota Kediri jumlah dana zakat cukup berkembang, perkembangan ini dapat dilihat dari hasil perolehan zakat, infak dan shadaqah Badan Amil Zakat Nasional (BAZNAS) kota Kediri, mengalami peningkatan setiap tahunnya. Hal ini menunjukkan masyarakat yang semakin percaya terhadap BAZNAZ sebagai Badan Amil Zakat yang profesional dan amanah. Tetapi BAZNAS juga harus meningkatkan pelayanan kepada masyarakat. Baznas kota Kediri memilik program untuk membangun kemadirian umat, 
Ghufraanaka, et al/Jurnal Ekonomi Syariah Teori dan Terapan Vol. 3 No. 5 Mei 2016: 375-390; PENGAKUAN, PENGUKURAN, PENYAJIAN, DAN PENGUNGKAPAN ASET KELOLAAN PADA LEMBAGA AMIL ZAKAT

mengurangi kemiskinan dan bantuan pendidikan. Dengan memberikan bantuan berupa modal usaha baik menengah dan kecil, bantuan konsumtif untuk fakir miskin, dan bantuan pendidikan beasiswa kepada anak yang kurang mampu.

Berdasarkan pada berita yang ditulis oleh Gumay (2014), Badan Amil Zakat (BAZ) Kediri, Jawa Timur, pada tahun 2014 menyalurkan zakat yang diperoleh dari sumbangan masyarakat, instansi, maupun para pegawai negeri sipil kepada 1.435 mustahik di 46 kelurahan yang tersebar di tiga kecamatan wilayah Kota Kediri. BAZ Kediri telah mendapatkan dana berupa zakat lebih dari Rp100 juta. Uang itu merupakan zakat yang terkumpul, dan akan dibagikan kepada masyarakat secara langsung. Selain itu, juga terdapat bantuan beras dari PT Gudang Garam, Tbk Kediri sebanyak tiga kuintal. Untuk pembagiannya, akan disalurkan kepada seluruh warga yang berhak menerima. Semua vang yang terkumpul itu akan dirupakan beras, sehingga lebih mudah pembagiannya. Selain dibagikan ke warga, beras itu akan dibagikan ke yayasan, pengurus madrasah, tempat pendidikan Al-Quran.

Mengelola zakat dalam semua prosesnya harus dilakukan dengan tanggung jawab. Allah maha mengetahui dan maha mendengar, maka lembaga pengelola zakat harus menyusun laporan keuangan dengan baik dan benar. Tetapi dewasa ini masih banyak BAZ dan LAZ yang aset pengelolaan pengeluaran dan penerimaan dana zakat tidak sesuai dengan PSAK 109, masih banyak yang menggunakan akuntansi konvensional, padahal sudah dikeluarkan peraturan tentang menggunakan PSAK 109 akuntansi zakat.

Berdasarkan penelitian terdahulu oleh Kristin (2011) yang berjudul "Penerapan Akuntansi Zakat Pada Lembaga Amil Zakat" menunjukkan dalam proses pelaporannya LAZ DPU DT Cabang Semarang hanya membuat laporan sumber dan penggunaan dana dan laporan penerimaan dan penggunaan dana, karena LAZ DPU DT Cabang Semarang belum mempunyai asset sendiri seperti tanah dan bangunan, sehingga LAZ DPU DT Cabang Semarang belum melakukan lima laporan keuangan menurut PSAK No. 109 diantaranya adalah neraca, laporan sumber dan penggunaan dana, laporan perubahan dana asset kelolaan, laporan arus kas, dan catatan atas laporan kevangan. Oleh karena itu LAZ DPU DT Cabang Semarang belum diaudit oleh akuntan publik dan belum sesuai dengan PSAK No. 109.

Muhamadiyah adalah organisasi Islam terbesar kedua setelah NU. Salah satu LAZ yang ada di Kota Kediri adalah Lembaga Amil Zakat Infak dan Shadaqah Muhamadiyah yang disingkat menjadi LAZISMU. LAZISMU Kota Kediri adalah salah satu lembaga resmi yang mengelola tentang zakat, infak, dan shadaqah milik 
Ghufraanaka, et al/Jurnal Ekonomi Syariah Teori dan Terapan Vol. 3 No. 5 Mei 2016: 375-390; PENGAKUAN, PENGUKURAN, PENYAJIAN, DAN PENGUNGKAPAN ASET KELOLAAN PADA LEMBAGA AMIL ZAKAT

persyarikatan Muhamadiyah. LAZISMU merupakan lembaga zakat yang terbesar kedua setelah NU. LAZISMU Muhamadiyah Kediri memiliki aset berupa rombong, klinik, dan zakat fitrah sebagai aset kelolaan. Dengan demikian penulis tertarik untuk mengetahui kesesuaian penerapan aset kelolaan, pengeluaran dan penerimaan dana zakat pada PSAK 109, sekecil apapun aset yang dimiliki suatu lembaga amil zakat harus memiliki pencatatan dan pelaporan kevangan, maka peneliti ingin mengetahui pencatatan yang dilakukan oleh LAZISMU Kota Kediri. Penelitian dengan judul "Pelaporan Aset Kelolaan pada LAZ , Studi Kasus di LAZISMU Muhamadiyah Kediri".

\section{Rumusan Masalah}

Dengan latar belakang yang sudah diuraikan diatas dapat dibuat dengan rumusan masalah dengan "Bagaimana pengakuan, pengukuran, penyajian, pengungkapan pada aset kelolaan LAZISMU?"

\section{Tujuan Penelitian}

Penelitian ini bertujuan untuk mengetahui pengakuan, pengukuran, penyajian, pengungkapan pada aset kelolaan LAZISMU

\section{Landasan Teori}

\section{Pengertian Zakat}

Zakat merupakan kewajiban yang harus dilakasanakn oleh setiap umat muslim. Ada beberapa pendapat mengenai pengertian zakat. Menurut Djuanda (2006: 13) "Zakat merupakan rukun islam ketiga disebut di dalam Al-
Qur'an pada ayat 82, didalam kitab-kitab hadist, yang kemudian dikembangkan oleh ijtihad manusia yang memenuhi syarat dalam berbagai aliran hukum islam." Sedangkan menurut Mahmud (2006: 1) "Zakat adalah suatu kewajiban bagi umat islam yang telah ditetapkan dalam Al-Qur'an, Sunah nabi, dan ijma' para ulama." Di antara tentang zakat adalah surat At-Taubah 103 :

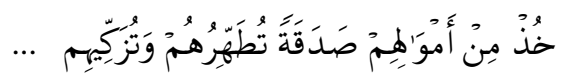

Khuzl min 'amwa>li>him s\}adaqatan tut\}ahhiruhum wa tuzzaki>hi>m

Artinya: " Ambillah zakat dari sebagian harta mereka, dengan zakat itu kamu membersihkan dan menyucikan mereka." Dan hikmah menunaikan zakat terdapat pada surat An-Nahl 71 :

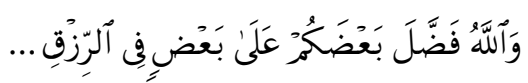

Wa'l-la>hu fad\}d\}ala ba'd\}akum 'ala> ba'd\}i fi> 'r-rizq

Artinya: "dan Allah melebihkan sebahagian kamu dari sebagian yang lain dalam hal rezki".

\section{Laporan Keuangan Amil Zakat}

Laporan kevangan amil zakat sangatlah penting bagi sebuah lembaga amil zakat untuk mengetahui segala aktivitas yang dilakukan oleh suatu lembaga zakat dan harus dicatata dengan baik dan benar agar dapat dipercaya oleh masyarakat. Menurut Kustiawan (2012:19) "Suatu laporan kevangan bermanfaat apabila informasi yang disajikan dalam laporan kevangan 
Ghufraanaka, et al/Jurnal Ekonomi Syariah Teori dan Terapan Vol. 3 No. 5 Mei 2016: 375-390; PENGAKUAN, PENGUKURAN, PENYAJIAN, DAN PENGUNGKAPAN ASET KELOLAAN PADA LEMBAGA AMIL ZAKAT

tersebut dapat dipahami, relevan, andal, dan dapat diperbandingkan." Laporan kevangan tidak menyediakan seluruh informasi yang mungkin dibutuhkan oleh pihak-pihak yang berkepentingan dengan Amil Zakat karena secara umum laporan kevangan hanya menggambarkan pengaruh keuangan dari kejadian masa lalu dan tidak diwajibkan untuk menyediakan informasi non keuangan. Amil Zakat perlu menyediakan informasi yang mempunyai pengaruh keuangan masa depan.

\section{PSAK 109 - Akuntansi Zakat}

PSAK 109 - akuntansi zakat telah disahkan oleh Dewan Standar Akuntansi Kevangan pada tanggal 26 Februari 2008. Pernyataan ini diterapkan untuk :

1. Mengatur pengakuan, pengukuran, penyajian dan pengungkapan transaksi zakat infak/ sedekah

2. Untuk amil yang menerima dan menyalurkan zakat dan infak atau sedekah

Pengakuan dan Pengukuran Transaksi Akuntansi Zakat

Berdasarkan PSAK 109- Akuntansi

Zakat paragraf 9-31pengakuan dan pengukuran akuntansi zakat sebagai berikut :

- Zakat

Pengakuan awal

1. Penerimaan zakat saat diakui pada saat kas atau aset lainnya diterima.

2. Zakat yang diterima dari muzakki diakui sebagai penambahan dana zakat: a) Jika dalam bentuk kas maka sebesar jumlah yang diterima

b) Jika dalam bentuk nonkas maka sebesar nilai wajar aset nonkas tersebut

3. Zakat yang diterima diakui sebagai dana amil untuk bagian amil dan dana zakat untuk bagian nonamil.

4. Jika muzakki menentukan mustahik yang harus menerima penyaluran zkat melalui amil maka aset zakat yang diterima seluruhnya diakui sebagai dana zakat. Jika atas jasa tersebut amil mendapatkan ujrah atau fee maka diakui sebagai penambah dana amil.

Pengukuran setelah pengakuan awal:

1. Penurunan nilai aset zakat diakui sebagai:

a. Pengurang dana zakat, jika terjadi tidak disebabkan oleh kelalaian amil

b. Kerugian dan pengurang dana amil, jika disebabkan oleh kelalaian amil

Penyaluran zakat:

1. Zakat yang disalurkan kepada mustahik diakui sebagai pengurang dana zakat sebesar:

a. Jumlah yang diserahkan, jika dalam bentuk kas

b. Jumlah tercatat, jika dalam bentuk nonkas

- Infak atau sedekah

Pengakuan awal: 
Ghufraanaka, et al/Jurnal Ekonomi Syariah Teori dan Terapan Vol. 3 No. 5 Mei 2016: 375-390; PENGAKUAN, PENGUKURAN, PENYAJIAN, DAN PENGUNGKAPAN ASET KELOLAAN PADA LEMBAGA AMIL ZAKAT

1. Infak atau sedekah yang diterima diakui sebagai dana infak atau sedekah terikat atau tidak terikat sesuai dengan tujuan pemberi infak atau sedekah sebesar :

a. Jumlah yang diterima, jika dalam bentuk kas

b. Nilai wajar, jika dalam bentuk nonkas

2. Infak atau sedekah yang diterima diakui sebagai dana amil untuk bagian amil dana dana infak atau sedekah untuk bagian amil penerima infak atau sedekah.

Pengukuran setelah pengakuan awal :

1. aset tidak lancar yang diterima oleh amil dan diamanahkan untuk dikelola dinilai sebesar nilai wajar saat penerimaannya dan diakui sebagai aset tidak lancar infak atau sedekah. Penyustuan dari aset tersebut diperlakukan sebagai pengurang dana infak atau sedekah terikat apabila penggunaan atau pengelolaan aset tersebut sudah ditentukan oleh pemberi.

2. Penurunan nilai aset infak atau sedekah tidak lancar diakui sebagai:

a. Pengurang dana infak atau sedekah, jika terjadi bukan disebabkan oleh kelalaian amil

b. Kerugian dan pengurang dana amil, jika disebabkan oleh kelalaian amil

Penyaluran infak atau sedekah :
1. Penyaluran dana atau infak sedekah diakui sebagai pengurang dana infak atau sedekah sebesar:

a. Jumlah yang diserahkan, jika dalam bentuk kas

b. Nilai tercatat aset yang dierahkan, jika dalam bentuk aset nonkas

Dana nonhalal:

2. Penerimaan nonhalal diakui sebagai dana nonhalal, yang terpisahkan dari dana zakat, dana infak atau sedekah dan dana amil. Aset nonhalal disalurkan sesuai dengan syariah.

\section{Penyajian dan Transaksi Akuntansi Zakat}

Amil menyajikan dana zakat, dana infak atau sedekah, dana amil, dan dana nonhalal secara terpisah dalam neraca (laporan posisi kevangan).

\section{Pengungkapan Transaksi Akuntansi Zakat}

1. Zakat

Amil harus mengungkapkan hal hal berikut terkait dengan transaksi zakat, tetapi tidak terbatas pada:

a. Kebijakan penyaluran zakat, seperti penentuan skala prioritas penyaluran, dan penerima

b. Kebujakan pembagian antara dana amil dan dana nonamil atas penerimaan zakat, seperti presentase pembagian, alasan, dan konsistensi kebijakan

c. Metode penentuan nilai wajar yang akan digunakan untuk penerimaan zakat berupa aset nonkas

d. Rincian jumlah penyaluran dana zakat yang mencakup jumlah beban pengelolaan dan jumlah 
Ghufraanaka, et al/Jurnal Ekonomi Syariah Teori dan Terapan Vol. 3 No. 5 Mei 2016: 375-390; PENGAKUAN, PENGUKURAN, PENYAJIAN, DAN PENGUNGKAPAN ASET KELOLAAN PADA LEMBAGA AMIL ZAKAT
dana yang diterima langsung mustahik

e. Hubungan istimewa antara amil dan mustahik yang meliputi:

i. Sifat hubungan istimewa

ii. Jumlah dan jenis aset yang disalurkan

iii. Presentase dari aset yang disalurkan tersebut dari total penyaluran selama periode

2. Infak atau sedekah

Amil harus megungkapkan hal-hal berikut terkait dengan transaksi infak atau sedekah, tetapi tidak terbatas pada:

a. Metode penentuan nilai wajar yang digunakan untuk penerimaan infak atau sedekah berupa aset nonkas

b. Kebijakan pembagian antara dana amil dan dana nonamil atas penerimaan infak atau sedekah, seperti presentase pembagian, alasan, dan konsistensi kebijakan

c. Kebijakan penyaluran infak atau sedekah, seperti penentuan skala prioritas penyaluran, dan penerima

d. Keberadaan dana infak atau sedekah yang tidak langsung disalurkan tetapi dikelola terleih dahulu, jika ada, maka harus diungkapkan jumlah dan presentase dari seluruh penerimaan infak atau sedekah selama periode pelaporan serta alasannya

e. Penggunaan dana infak atau sedekah menjadi aset kelolaan yang diperuntukkan bagi yang berhak, jika ada, jumlah dan
presentase terhadap seluruh penggunaan dana infak atau sedekah serta alasannya.

f. Rincian julah penyaluran dana infak atau sedekah yang mencakup jumlah beban pengelolaan dan jumlah dana yang diterima langsung oleh penerima infak atau sedekah

g. Rincian dana infak atau sedekah berdasarkan peruntukannya, terikat dan tidak terikat

h. Hubungan istimewa antara amil dengan penerima infak atau sedekah yang meliputi:

i. Sifat hubungan istimewa

ii. Jumlah dan jenis aset yang dislurkan

iii. Presentase dari aset yang disalurkan tersebut dari total penyaluran selama periode

3. Selain membuat pengungkapan amil mengungkapkan hal-hal berikut:

a. Keberadaan dana nonhalal, jika ada, diungkapkan mengenai kebijakan atas penerimaan dan penyaluran dana, alasan, dan jumlahnya

b. Kinerja amil atas penerimaan dan penyaluran dana zakat dan dana infak atau sedekah.

\section{Metode Peneletian}

\section{Pendekatan Penelitian}

Penelitian ini menggunakan pendekatan kualitatif deskriptif. Bodgan dan Taylor dalam Moleong (2006: 4) mendefinisikan penelitian kualitatif sebagai prosedur penelitian yang 
Ghufraanaka, et al/Jurnal Ekonomi Syariah Teori dan Terapan Vol. 3 No. 5 Mei 2016: 375-390; PENGAKUAN, PENGUKURAN, PENYAJIAN, DAN PENGUNGKAPAN ASET KELOLAAN PADA LEMBAGA AMIL ZAKAT

menghasilkan data deskriptif berupa katakata tertulis atau lisan dari orang-orang dan perilaku yang dapat diamati.

Penelitian deskriptif menurut Arikunto (1998: 309) adalah penelitian yang dimaksudkan untuk mengumpulkan informasi mengenai status suatu gejala yang ada, yaitu keadaan gejala menurut apa adanya pada saat penelitian dilakukan. Tujuan dari penelotian deskriptif adalah membuat deskripsi, gambaran secara sistematis, aktual dan akurat mengenai fakta-fakta, sifat serta hubungan antar fenomena yang dimiliki.

Berdasarkan pengertian diatas dapat dikemukakan bahwa penelitian deskriptif adalah penelitian yang berdasarkan apa yang ada didalam penelitian atau berdasarkan fakta yang ada pada saat penelitian berlangsung, dan menghubungkan fenomenafenomena yang terjadi serta menganalaisa berdasarkan konsepkonsep yang telah dikembangkan sebelumnya sehingga memudahkan peneliti memecahkan masalah.

Adapun rumusan masalah dalam penelitian ini adalah "Bagaimana pengakuan, pengukuran, penyajian, dan pengungkapan aset kelolaan pada LAZ?". Berdasarkan pada latar belakang masalah, perumusan masalah, serta tujuan penelitian, maka strategi yang digunakan dalam penelitian ini adalah studi kasus. Studi kasus merupakan strategi yang apabila pertanyaan rumusan masalah suatu penelitian dengan menggunakan how atau why, bila peneliti hanya memiliki sedikit peluang untuk mengontrol peristiwa-peristiwa yang akan diselidiki, dan fokus terletak pada fenomena kontemporer (masa kini) di dalam konteks kehidupan nyata (Yin, 2014: 1).

Alasan penggunaan strategi studi kasus adalah: 1) Hasil penelitian strategi studi kasus tidak memungkinkan untuk dimanipulasi karena peneliti tidak memiliki peluang untuk mengontrol peristiwaperistiwa yang akan terjadi, 2) Merupakan strategi yangsesuai dengan pertanyaan penelitian dalam penelitian ini adalah "Bagaimana", 3) fokus penelitian terletak pada fenomena kontemporer (masa kini) dalam konteks kehidupan nyata. Fokus penelitian ini terletak pada penerapan pencatatan dan pelaporan aset kelolaan atas akuntansi zakat pada LAZIZMU Muhamadiyah Kediri. Data yang dibutuhkan tidak hanya data historis tetapi juga membutuhkan wawancara, dan observasi langsung di lapangan.

\section{Jenis dan Sumber Data}

Jenis data yang digunakan dalam penelitian ini adalah data kuantitatif berupa angka-angka laporan keuangan. Selain itu dikumpulkan pula data kualitatif mengenai sejarah serta gambaran umum LAZ, kebijakan akuntansi dan sebagainya.

Dalam penelitian ini, data yang digunakan adalah data primer dan data sekunder. Data primer adalah data dari informasi yang dikumpulkan penulis dari instansi selama kegiatan penelitian. Data 
Ghufraanaka, et al/Jurnal Ekonomi Syariah Teori dan Terapan Vol. 3 No. 5 Mei 2016: 375-390; PENGAKUAN, PENGUKURAN, PENYAJIAN, DAN PENGUNGKAPAN ASET KELOLAAN PADA LEMBAGA AMIL ZAKAT

yang berkaitan dengan penelitian ini diperoleh dari sumber intern instansi dan wawancara yang dilakukan dengan pihak terkait. Data sekunder adalah data yang diperoleh peneliti yang berasal dari riset, laporan-laporan antara lain bukti transaksi; jurnal; buku besar; dokumendokumen yang berhubungan dan mendukung serta dapat membantu memecahkan permasalahan ini.

\section{Prosedur dan Teknik Pengumpulan Data}

Sesuai dengan prosedur penelitian pada umumnya, maka prosedur pengumpulan data skripsi adalah sebagai berikut:

1. Survey Pendahuluan

Dilaksanakan dengan tujuan untuk mendapatkan gambaran umum mengenai LAZ yang berkaitan dengan masalah yang akan diteliti.

\section{Studi Kepustakaan}

Prosedur ini dilaksanakan dengan tujuan untuk memperoleh landasan teori dan implementasinya melalui literatur, laporan, makalah, jurnal, dan artikel yang berkaitan dengan permasalahan yang ada serta berguna bagi penyusunan skripsi. Studi kepustakaan difokuskan pada literatur mengenai LAZ, akuntansi zakat, dan akuntansi syariah.

\section{Penelitian Lapangan}

Langkah ini bertujuan untuk melihat secara lebih jelas serta memperoleh data yang akurat sebagai masukan dalam proses analisis selanjutnya. Penelitian dilaksanakan melalui:

a. Obsevasi
Tahapan observasi menurut Sugiyono (2012: 230) dibagi menjadi tiga, yaitu:

\section{i. Observasi Deskriptif}

Pada tahap ini peneliti melakukan penjelajahan umum dan menyeluruh, melakukan deskrpsi terhadap semua yang dilihat, didengar, dan dirasakan. Semua data direkam dan hasil obsevasi masih belum tertata. Pada tahap ini peneliti memperoleh gambaran secara umum mengenai alur pencatatan dan pelaporan LAZ.

ii. Observasi Terfokus

Pada tahap ini data yang belum tertata disempitkan dan difokuskan pada aspek tertentu karena peneliti melakukan analisis taksonomi sehingga dapat menemukan fokus. Di dalam tahap ini penulis fokus kepada pelaporan dan pencatatan aset kelollan yang digunakan oleh LAZISMU Kota Kediri.

iii. Observasi Terseleksi

Pada tahap ini telah menguraikan fokus yang ditemukan sehingga datanya lebih rinci. Pada tahap ini peneliti menemukan karakteristik, kontras-kontras perbedaan dan kesamaan antar kategori yang lain.

\section{b. Wawancara}

Mengadakan tanya jawab secara langsung dengan ketua dan bagian pembukuan pada LAZISMU Kota Kediri untuk mendapatkan data yang dibutuhkan. Ketua merupakan pihak yang mengetahui atas seluruh aktifitas LAZISMU 
Ghufraanaka, et al/Jurnal Ekonomi Syariah Teori dan Terapan Vol. 3 No. 5 Mei 2016: 375-390; PENGAKUAN, PENGUKURAN, PENYAJIAN, DAN PENGUNGKAPAN ASET KELOLAAN PADA LEMBAGA AMIL ZAKAT

Kota Kediri. Bendahara dan ketua LAZISMU merupakan informan dalam penelitian ini karena bagian pembukuan merupakan pihak yang mengetahui atas seluruh pencatatan dan pelaporan aset kelolaan pada LAZISMU Kota Kediri.

\section{c. Dokumentasi}

Dokumentasi dalam penelitian ini adalah pencatatan dan pelaporan aset kelolaan yang terdapat pada buku harian kas LAZISMU Kota Kediri.

\section{Unit Analisis dan pertanyaan Protokol}

Yang sudah dikemukakan pada rumusan masalah, yang menjadi unit analisis dalam penelitian ini adalah penerapan akuntansi zakat pada pencatatan dan pelaporan aset kelolaan LAZISMU Kota Kediri.

Untuk mendapatkan data tersebut, dibutuhkan pertanyaan protokol sebagai berikut:

a. Bagaimana pelaporan dan pencatatan saat pembelian aset kelolaan?

b. Bagaimana pelaporan dan pencatatan pada saat pengelolaan aset kelolaan?

C. Bagaimana pelaporan dan pencatatan pada saat penjualan?

\section{Teknik Validasi}

Dari empat metode yang dikemukakan oleh Sugiyono (2012: 241), peneliti menggunakan metode triangulasi sumber data untuk menguji kreadibilitas data dilakukan dengan cara mengecek data yang telah diperoleh melalui beberapa sumber. Misalnya, selain melalui wawancara dan observasi, peneliti juga menggunakan observasi terlibat, dokumen tertulis, arsip, dokumen sejarah, catatan resmi, catatan atau tulisan pribadi dan gambar atau foto. Dari metode ini, peneliti akan membandingkan keselarasan antara wawancara dengan pihak terkait, observasi di lapangan, dan dibuktikan dengan arsip dokumen yang ada, sehingga data dapat akurat dan dapat dipertanggungjawabkan.

Triangulasi sumber menguji kredibilitas data dengan cara mengecek data yang didapat dari beberapa sumber. Dalam penelitian ini, untuk menguji kredibilitas data tentang PSAK 109 dilakukan dengan mengkroscek data yang diperoleh dari beberapa informan terpilih. Selanjutnya data yang terkumpul dideskripsikan dan dikategorisasikan berdasarkan pandangan yang sama, berbeda dan spesifik. Data yang telah dianalisis menghasilkan kesimpulan yang selanjutnya akan dimintakan kesepakatan.

Triangulasi teknik dilakukan dengan cara mengkroscek data yang didapat dari informan-informan terpilih dengan bukti-bukti yang ada. Bukti tersebut berupa dokumen-dokumen yang mendukung penelitian, yaitu PSAK 109 yang mengatur tentang akuntansi zakat.

\section{Teknik Analisis}

Peneliti ini menggunakan teknik analisis data yang berupa pengolahan data yang diperoleh peneliti selama dilapangan serta mengolah hasil wawancara dan dokumentasi. Tekhnik 
Ghufraanaka, et al/Jurnal Ekonomi Syariah Teori dan Terapan Vol. 3 No. 5 Mei 2016: 375-390; PENGAKUAN, PENGUKURAN, PENYAJIAN, DAN PENGUNGKAPAN ASET KELOLAAN PADA LEMBAGA AMIL ZAKAT

yang digunakan untuk menganalisa data menurut Spradley dalam Sugiyono (2012: 255) ada tiga:

a. Analisis Domain

Memperoleh gambaran yang umum dan menyeluruh dari obyek penelitian atau situasi sosial. Ditemukan berbagai domain atau kategori yang didapat dari pertanyaan grand dan minitour. Peneliti menetapkan domain tertentu sebagai pijakan untuk peneliti, yaitu proses penerimaan aset, pengelolaan aset, dan pada saat penyaluran aset yang terkandung di dalam proses perlakuan akuntansi mulai dari pengakuan, pengukuran, pengungkapan sampai penyajian yang dilakukan oleh LAZISMU Muhamadiyah kediri.

b. Analisis Taksonomi

Domain yang terpilih selanjutnya dijabarkan menjadi lebih rinci untuk mengetahui perlakuan akuntansinya. Dilakukan dengan observasi terfokus pada domain terpilih. Selanjutnya, domain yang telah ditentukan dalam analisa domain selanjutnya diperinci dan diseleksi.

\section{Pembahasa}

\section{Perlakuan Akuntansi Aset Kelolaan Berdasarkan PSAK 109}

LAZISMU dalam pencatatan dan pelaporannya hanya melakukan pencatatan buku kas masuk dan kas keluar serta melaporkan pada Laporan Pentasharufan tahunan sehingga tidak sesuai dengan PSAK 109. Setelah melihat pencatatan yang dilakukan oleh LAZISMU bagaimana perlakuan akuntansi mengenai akuntansi zakatnya yang telah disajikan dalam laporan penerimaan kas masuk dan kas keluar diatas, dibawah ini menunjukkan perbandingan perlakuan akuntansi LAZISMU dengan PSAK 109. Terdapat beberapa transaksi yang dapat diperbandingkan pada saat menerima aset kelolaan, mengelola aset kelolaan dan menyalurkan aset kelolaan, berikut adalah proses pencatatan yang seharusnya dilakukan oleh LAZISMU:

Pada Saat Menerima Zakat, Infak, Dan Shadaqah.

LAZISMU tidak melakukan penjurnalan terkait pada saat menerima zakat, infak dan shadaqah.

a) Jurnal penerimaan kas yang diperuntukkan menerima zakat berdasarkan PSAK 109 adalah sebagai berikut:

Tabel 1.

Jurnal Penerimaan Kas (zakat)

\begin{tabular}{|l|c|c|c|}
\hline Tgl & Rekening & Debit & Kredit \\
\hline & Dr. Kas & Rp 276.190.000 & \\
\hline & $\begin{array}{c}\text { Cr. Dana } \\
\text { Zakat }\end{array}$ & & Rp 276.190.000 \\
\hline \multicolumn{2}{|c|}{ Sumber: data primer, 2016 (diolah) }
\end{tabular}

Tabel 1. menunjukkan penerimaan kas (zakat) yang diterima oleh LAZISMU. LAZISMU melakukan pencatatan dana zakat yang diterima dari muzakki diakui sebagai penambahan dana zakat dalam bentuk kas sebesar jumlah yang diterima. Namun pencatatan dana zakat, hanya dilakukan pada pencatatan buku kas masuk saja, tidak tercatat dalam jurnal.

b) Jurnal penerimaan dana zakat fitrah berupa beras yang seharusnya sesuai 
Ghufraanaka, et al/Jurnal Ekonomi Syariah Teori dan Terapan Vol. 3 No. 5 Mei 2016: 375-390; PENGAKUAN, PENGUKURAN, PENYAJIAN, DAN PENGUNGKAPAN ASET KELOLAAN PADA LEMBAGA AMIL ZAKAT

dengan PSAK 109 adalah sebagai berikut:

Tabel 2.

Jurnal Penerimaan Dana Zakat Fitrah Berupa Beras infak dan shadaqah hanya dilakukan pada pencatatan buku kas masuk saja tidak tercatat dalam jurnal.

\section{Pada Saat Pengelolaan Aset Kelolaan.}

\begin{tabular}{|c|c|c|c|c|}
\hline Tgl & Rekening & Debit & Kredit & LAZISMU tidak melakukan penjurnalan \\
\hline & $\begin{array}{l}\text { Dr. Persediaan } \\
\text { (Beras) }\end{array}$ & $\operatorname{Rp} 23.080 .000$ & & terkait pada saat pengelolaan aset \\
\hline & Cr. Dana Zakat & & Rp 23.080.000 & Keloladan, LALISMU nanya mencatat pe \\
\hline
\end{tabular}

Tabel 2. menunjukkan jurnal penerimaan zakat fitrah berupa beras yang diterima oleh LAZISMU. LAZISMU melakukan pencatatan dana zakat fitrah yang diterima dari muzakki diakui sebagai penambahan dana zakat dalam bentuk persediaan sebesar jumlah yang diterima. Namun pencatatan dana zakat, infak dan shadaqah hanya dilakukan pada pencatatan buku kas masuk saja tidak tercatat dalam jurnal.

c) Jurnal penerimaan dana zakat fitrah berupa uang yang seharusnya sesuai dengan PSAK 109 adalah sebagai berikut:

Tabel 3. Jurnal Penerimaan Dana Zakat Fitrah Berupa Uang

\begin{tabular}{|c|c|l|c|}
\hline Tgl & Rekening & \multicolumn{1}{|c|}{ Debit } & Kredit \\
\hline & Dr. Kas & $\begin{array}{l}\mathrm{Rp} \\
12.650 .000\end{array}$ & \\
\hline & $\begin{array}{c}\text { Cr. } \\
\text { Dana zakat }\end{array}$ & & Rp 12.650.000 \\
\hline
\end{tabular}

Sumber: data primer, 2016 (diolah)

Tabel 3. menunjukkan dana zakat fitrah yang diterima oleh LAZISMU berupa vang. LAZISMU melakukan pencatatan dana zakat fitrah yang diterima dari muzakki diakui sebagai penambahan dana zakat dalam bentuk kas sebesar jumlah yang diterima. Namun pencatatan dana zakat, melaporkannya setiap tahun pada laporan pentasharufan.

a) Jurnal pemindahbukuan dari kas ke bank yang seharusnya sesuai dengan PSAK 109 adalah sebagai berikut:

Tabel 4.

Jurnal Pemindahbukuan dari Kas ke Bank

\begin{tabular}{|c|c|c|c|}
\hline Tgl & Rekening & \multicolumn{1}{|c|}{ Debit } & Kredit \\
\hline & Dr. Kas & $\begin{array}{l}\text { Rp } \\
279.050 .000\end{array}$ & \\
\hline & $\begin{array}{l}\text { Cr. } \\
\text { Bank } \\
\end{array}$ & & Rp 279.050.000 \\
& Muamalat & \\
\hline \multicolumn{3}{|c|}{ Sumber: data primer, 2016 (diolah) }
\end{tabular}

Tabel 4. menunjukkan jurnal pemindahbukuan dari kas ke Bank Muamalat yang seharusnya dicatat oleh LAZISMU. LAZISMU tidak melakukan pencatatan apapun terkait dengan pemindahbukuan dari kas ke bank.

b) Jurnal pembelian aset tetap kelolaan LAZISMU yang seharusnya sesuai dengan PSAK 109 adalah sebagai berikut:

Tabel 5.

Jurnal Pembelian Aset tetap

\begin{tabular}{|c|l|l|l|}
\hline Tgl & \multicolumn{1}{|c|}{ Rekening } & \multicolumn{1}{c|}{ Debit } & \multicolumn{1}{c|}{ Kredit } \\
\hline & $\begin{array}{l}\text { Dr. Aset tetap } \\
\text { kelolaan } \\
\text { (rombong) }\end{array}$ & $\begin{array}{l}\mathrm{Rp} \\
4.500 .000\end{array}$ & \\
\hline & Cr. Kas & & $\mathrm{Rp}$ \\
& & & 4.500 .000 \\
\hline
\end{tabular}

Sumber: data primer, 2016 (diolah) 
Ghufraanaka, et al/Jurnal Ekonomi Syariah Teori dan Terapan Vol. 3 No. 5 Mei 2016: 375-390; PENGAKUAN, PENGUKURAN, PENYAJIAN, DAN PENGUNGKAPAN ASET KELOLAAN PADA LEMBAGA AMIL ZAKAT

Tabel 5. menunjukkan jurnal pembelian aset tetap yang seharusnya dicatat oleh LAZISMU. LAZISMU hanya melakukan pencatatan pada buku kas keluar saja, terkait pembelian 3 rombong, yang seharusnya menurut PSAK 109 pencatatan debet akun aset tetap dilakukan pada saat aset tersebut diterima dan siap untuk dioperasikan. Namun LAZISMU hanya mencatat pada buku kas keluar saja, tidak melakukan penjurnalan apapun terkait dengan pembelian rombong tersebut.

c) Berdasarkan PSAK 109 aset kelolaan yang jumlahnya material diharuskan untuk melakukan penyusutan dengan menggunakan metode disesuaikan dengan kebijakan akuntansi LAZISMU. dibawah ini adalah contoh perhitungan untuk penyusutan rombong dilakukan setiap 3 tahun:

Harga perolehan rombong:

@ Rp $1.500 .000 \times 3=$ Rp. 4.500 .000

Diasumsikan penyusutan selama 3 tahun:

$$
\frac{R p \cdot 4.500 .000}{3 \text { tahun }}=R p .1 .500 .000
$$

Jurnal penyusutan aset tetap yang sesuai dengan PSAK 109 adalah sebagai berikut:

Tabel 6. Jurnal Penyusutan Aset Tetap

\begin{tabular}{|c|c|c|c|}
\hline Tgl & Rekening & Debit & Kredit \\
\hline & $\begin{array}{l}\text { Dr. Peyusutan aset } \\
\text { tetap } \\
\text { (rombong) }\end{array}$ & $\begin{array}{l}\mathrm{Rp} \\
1.500 .000\end{array}$ & \\
\hline & $\begin{array}{c}\text { Cr. Akumulasi } \\
\text { Penyusutan }\end{array}$ & & $\begin{array}{l}\mathrm{Rp} \\
1.500 .000\end{array}$ \\
\hline
\end{tabular}
Sumber: data primer, 2016 (diolah)

Tabel 6. menunjukkan penyusutan aset tetap (rombong) yang seharusnya dicatat oleh
LAZISMU. LAZISMU memiliki aset berupa rombong tetapi LAZISMU tidak melakukan pencatatan apapun terkait penyusutannya, yang seharusnya memiliki penyusutan untuk aset tetap berupa peralatan, menurut PSAK 109 paragraf 23 bahwa, "Aset tidak lancar yang diterima oleh amil dan diamanahkan untuk dikelola dinilai sebesar nilai wajar saat penerimaannya dan diakui sebagai aset tidak lancar infak / sedekah, penyusutan dari aset tersebut diperlakukan sebagai pengurang dana infak / sedekah terikat apabila penggunaan atau pengelolaan aset tersebut sudah ditentukan." Namun LAZISMU tidak mencatat terkait dengan penyusutan aset tersebut dan tidak melakukan penjurnalan.

\section{Pada Saat Penyaluran Aset Kelolaan.}

LAZISMU tidak melakukan penjurnalan terkait pada saat penyaluran aset kelolaan. Hanya melakukan pencatatan pada buku kas keluar saja.

a) Jurnal penyaluran zakat fitrah yang seharusnya sesuai dengan PSAK 109 dilakukan oleh LAZISMU adalah sebagai berikut:

Tabel 7. Jurnal Pengeluaran Kas

\begin{tabular}{|c|l|l|l|}
\hline Tgl & Rekening & \multicolumn{1}{|c|}{ Debit } & \multicolumn{1}{|c|}{ Kredit } \\
\hline & Dr. Dana & Rp & \\
& zakat & 23.080 .000 & \\
\hline & Cr. & & Rp \\
& Persediaa & & 23.080 .000 \\
& $\mathrm{n}$ & & \\
\hline
\end{tabular}

Sumber: data primer, 2016 (diolah)

Tabel 7. menunjukkan jumlah dana zakat fitrah yang disalurkan untuk fakir miskin oleh LAZISMU. LAZISMU dalam menyalurkan zakat fitrah hanya 
Ghufraanaka, et al/Jurnal Ekonomi Syariah Teori dan Terapan Vol. 3 No. 5 Mei 2016: 375-390; PENGAKUAN, PENGUKURAN, PENYAJIAN, DAN PENGUNGKAPAN ASET KELOLAAN PADA LEMBAGA AMIL ZAKAT

melakukan pencatatan pada buku kas keluar saja, tidak melakukan penjurnalan terkait dengan penyaluran zakat fitrah tersebut yang sesuai dengan PSAK 109.

LAZISMU menyalurkan zakat, infak, dan shadaqah sesuai dengan Usulan SPZ masing-masing ranting di kelurahan. LAZISMU melakukan pencatatan dan diakui sesuai dengan jumlah yang disalurkan kepada mustahiq, tetapi yang benar menurut PSAK 109 pada paragraf 17 dan 29 bahwa, "zakat, infak, dan shadaqah yang disalurkan kepada mustahiq diakui sebagai pengurang dana zakat sebesar jumlah yang diserahkan, jika dalam bentuk kas, jumlah tercatat, jika dalam bentuk aset nonkas." Namun LAZISMU tidak melakukan penjurnalan terkait penyaluran aset tersebut.

LAZISMU memiliki aset berupa rombong yang akan disalurkan untuk pemberdayaan ekonomi, LAZISMU tidak melakukan pencatatan, pencatatan, pengungkapan, pengukuran, dan pengungkapan terkait dengan penyaluran aset tersebut, seharusnya menurut PSAK 109 paragraf 17 dan 29 bahwa, "zakat, infak, dan shadaqah yang disalurkan kepada mustahiq diakui sebagai pengurang dana zakat sebesar jumlah yang diserahkan, jika dalam bentuk kas, jumlah tercatat, jika dalam bentuk aset nonkas." Namun LAZISMU tidak melakukan penjurnalan terkait dengan penyaluran aset tersebut. 3 rombong dan klinik itu dimiliki dan dikelola oleh LAZISMU, tetapi dalam pencatatannya dalam menyalurkan aset tersebut, LAZISMU tidak melakukan pencatatan apapun terkait dengan penyaluran aset kelolaan tersebut.

\section{Simpulan}

Berdasarkan analisis hasil penelitian yang dilakukan pada perlakuan akuntansi yang diterapkan LAZISMU terhadap aset kelolaan dari tahap menerima aset kelolaan, selama proses mengelola hingga saat penyaluran aset kelolaan dapat disimpulkan bahawa:

a. Pada saat pengakuan dan pengukuran pada saat menerima aset kelolaan sudah sesuai dengan PSAK 109, sedangkan penyajian dan pengungkapannya pada saat menerima aset kelolaan, tidak sesuai dengan PSAK 109.

b. Pada saat pengelolaan aset kelolaan, dalam hal pengakuan, pengukuran, pengungkapan dan penyajian pada saat pemindahbukuan dari kas ke bank tidak sesuai dengan PSAK 109. Sedangkan pada saat pembagian porsi dana amil dan penggunaan dana untuk aktivitas operasional dana amil dalam hal pengakuan dan pengukurannya sudah sesuai dengan PSAK 109, namun pengungkpan dan penyajiannya tidak sesuai dengan PSAK 109. Pada penyusutan aset tetap dalam hal pengakuan, pengukuran, penyajian dan 
Ghufraanaka, et al/Jurnal Ekonomi Syariah Teori dan Terapan Vol. 3 No. 5 Mei 2016: 375-390; PENGAKUAN, PENGUKURAN, PENYAJIAN, DAN PENGUNGKAPAN ASET KELOLAAN PADA LEMBAGA AMIL ZAKAT

\author{
pengungkapan tidak sesuai \\ dengan PSAK 109. \\ c. Pada saat penyaluran aset \\ kelolaan, dalam hal pengakuan \\ dan pengukuran sudah sesuai \\ dengan PSAK 109, namun \\ pengungkapan dan penyajiannya \\ tidak sesuai dengan PSAK 109.
}

\section{DAFTAR PUSTAKA}

Arikunto, S. 1998. Prosedur Penelitian Suatu Pendekatan Praktek. Jakarta: PT Rineka Cipta.

Azra, Azyumardi. 2003. Berderma Untuk Semua. Jakarta: Teraju.

BAZNAS Kota Kediri. 2014. Jumlah Dana Zakat yang Diterima Dari Muzakki Edisi Januari 2011 sampai Desember 2014.

Djuanda, Gustian. 2006. Pelaporan Zakat

Pengurang Pajak Penghasilan. Jakarta: PT.

Raja Grafindo Persada.

Departemen Agama RI. 2007. Al-Qur'an terjemahan perkata. Bandung: Syamil AlQur'an.

Ferdiansyah, wavi. 2013. Faktor Yang Berpengaruh Terhadap Pemahaman Akuntan Tentang PSAK No. 109 Pada Lembaga Zakat Di Surabaya. Fakultas Ekonomi Dan Bisnis Universitas Airlangga.

Gumay, Akbar Nugroho. 2014. BAZ Kediri Salurkan Zakat Kepada 1435 Mustahik.(Online), (http://ramadhan.ant aranews.com/berita/327856/baz-kediri salurkan-zakat-kepada-1435-mustahik, diakses 20 September 2015).
Hafidhuddin, Didin. 2002. Zakat Dalam

Perekonomian Modern. Jakarta:

Gema Insani.

Harahap, Sofyan, Syafri. 2004. Ekonomi Islam. Jakarta: Bumi Aksara.

Ikatan Akuntan Indonesia. 2008. Standar Akuntansi Keuangan PER 26 Februari 2008 -PSAK 109. Jakarta: Salemba Empat.

Kementrian Agama Republik Indonesia.

2011. Undang-Undang Republik Indonesia No. 23 tentang pengelolaan zakat. Versi

pdf.http://dki.kemenag.go.id/file/file/U

ndangundang/mova1363200664.pdf

(diakses pada 15 Desember 2015 pukul 13.00).

Kristin, 2011. Penerapan Akuntansi Zakat Pada Lembaga Amil Zakat (Studi

Kasus Pada LAZ DT Cabang Semarang). Skripsi IAIN Walisongo Semarang.

Kustiawan, Teten. 2012. Pedoman

Akuntansi Amil Zakat (Panduan Implementasi Penyusunan Laporan KevanganBerbasis PSAK 109. Jakarta: Forum Zakat (FOZ).

Mahmud, Al Ba'iy Abdul Al Hamid. 2006.

Ekonomi Zakat Sebuah Kajian Moneter dan keuangan Syariah. Jakarta: PT. Raja Grafindo Persada.

Moleong, Lexy. 2002. Metodologi

Penelitian Kualitatif. Bandung: PT. Remaja Rosdakarya.

Pusat Badan Amil Zakat Nasional. 2014.

Jumlah Dana Zakat yang di terima Dari Muzakki Edisi Januari 2011 sampai 
Ghufraanaka, et al/Jurnal Ekonomi Syariah Teori dan Terapan Vol. 3 No. 5 Mei 2016: 375-390; PENGAKUAN, PENGUKURAN, PENYAJIAN, DAN PENGUNGKAPAN ASET KELOLAAN PADA LEMBAGA AMIL ZAKAT

Desember

2014.

www.pusat.baznas.go.id

Sudarsono, Heri. 2008. Bank dan Lembaga

Kevangan Syariah Edisi Ketiga. Cetakan pertama. Yogyakarta: Ekonisia.

Sugiyono. 2012. Metode Penelitian

Pendidikan. Bandung: Alfabeta.

Syahrul dan Afdi Nizar. 2000. Kamus

Akuntansi. Jakarta: Citra Harta Prima.

Yin, Robert K. 2014. Studi Kasus Desain dan

Metode. Jakarta: PT. Raja Grafindo Persada.

Zuhayly, Wahbah. 2008. Zakat Kajian

Berbagai Mazhab. Bandung: PT. Remaja Rosdakarya. 